\section{Commentary: Making a difference: Pressure differential corrected during thoracoabdominal aortic repair}

\author{
Heidi Reich, MD, a and Danny Ramzy, MD, $\mathrm{PhD}^{\mathrm{b}}$
}

In the modern era, open surgical repair of thoracoabdominal aortic disease has an estimated mortality of approximately $10 \%$, and although patients with Marfan syndrome frequently have more complex, extensive pathologies, results are also good-to-excellent for this subset of patients, with mortality ranging from $0 \%$ to $7 \%{ }^{1}$ In this issue of JTCVS Techniques, Tully and colleagues ${ }^{2}$ from St Bartholomew's Hospital in London share an interesting case regarding the recognition and correction of pressure gradient at the proximal anastomosis in a patient with Marfan syndrome during thoracoabdominal repair of a chronic type $\mathrm{B}$ aortic dissection. When left heart bypass was discontinued, a $>70-\mathrm{mm} \mathrm{Hg}$ discrepancy was noted between the right radial and femoral arterial lines. This finding immediately raises concerns for an anastomotic issue, given the expectation of little-to-no gradient across an aortic-caliber anastomosis, and warrants an urgent investigation of the cause. The authors confirmed the gradient by direct aortic pressure measurement and transesophageal echocardiography. They localized the issue to the proximal aortic anastomosis, which demonstrated flow acceleration and a pressure gradient in both systole and diastole. A gradient that persists throughout the entire cardiac cycle indicates a fixed obstruction, which would definitely require a revision. This finding is what the authors call a pseudocoarctation.

From ${ }^{\mathrm{a} C e n t r a l ~ C a l i f o r n i a ~ H e a r t ~ a n d ~ L u n g ~ S u r g e r y, ~ C l o v i s ; ~ a n d ~}{ }^{\mathrm{b}}$ Smidt Heart Institute, Cedars-Sinai Medical Center, Los Angeles, Calif.

Disclosures: The authors reported no conflicts of interest.

The Journal policy requires editors and reviewers to disclose conflicts of interest and to decline handling or reviewing manuscripts for which they may have a conflict of interest. The editors and reviewers of this article have no conflicts of interest.

Received for publication Jan 27, 2021; revisions received Jan 27, 2021; accepted for publication Jan 28, 2021; available ahead of print Feb 1, 2021.

Address for reprints: Danny Ramzy, MD, PhD, Cedars-Sinai Medical Center, $127 \mathrm{~S}$ San Vicente Blvd, Suite A3105, Los Angeles, CA 90048 (E-mail: danny.ramzy@ cshs.org).

JTCVS Techniques 2021;6:110-1

2666-2507

Copyright $@ 2021$ The Authors. Published by Elsevier Inc. on behalf of The American Association for Thoracic Surgery. This is an open access article under the CC BY-NCND license (http://creativecommons.org/licenses/by-nc-nd/4.0/).

https://doi.org/10.1016/j.xjtc.2021.01.038
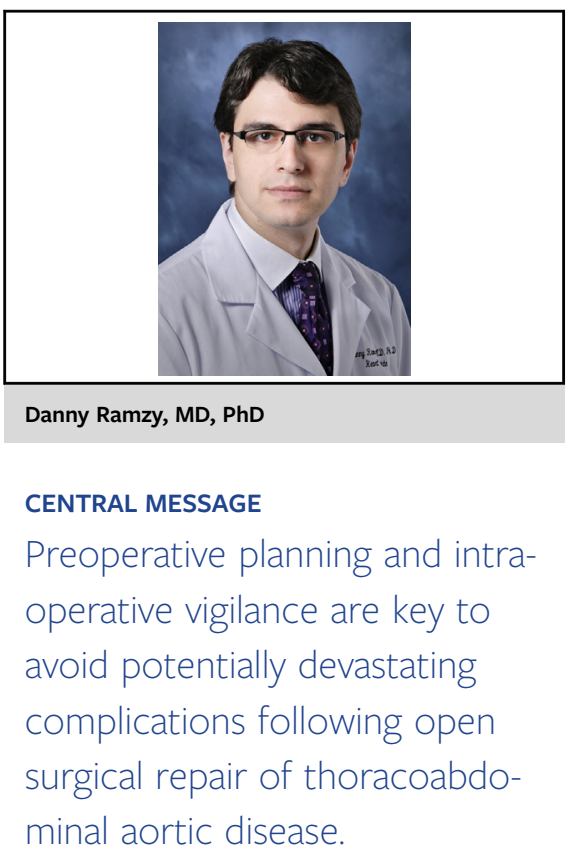

The traditional description of pseudocoartation is an aortic condition that radiographically appears similar to coarctation but with little-to-no gradient. The hallmarks of pseudocoarctation include an elongated, tortuous, S-shaped aorta, often with a prominent kink at the level of the isthmus, without a significant gradient. ${ }^{3}$ In contrast, the authors encountered a residual dissection flap proximal to the proximal anastomosis creating a coarctation-like pressure gradient. Confirming the location and cause of the issue is critical for an optimal correction and result. The authors rightfully recrossclamped the aorta proximal to the left subclavian artery for the revision and extended the surgical fenestration more proximally. This maneuver relieved the pressure gradient, and the patient recovered uneventfully. The authors should be commended for this rescue of a potentially catastrophic complication.

The differential diagnosis for the pressure gradient suggests many causations and issues. These include graft redundancy, twist, or kink; misidentification of the true versus false lumen; and size discrepancy between the native aorta and graft. Considerations also include flow-limiting intussusception of flap; excessive narrowing of the anastomosis; extrinsic compression; aortic injury at crossclamp site; or retrograde acute type A aortic dissection. Postoperative computed tomography or invasive angiogram could have provided additional diagnostic information, although we agree with their approach of not leaving the operating room until this potentially serious complication had been addressed. 
All strategies to avoid leaving residual flow-limiting dissection flap tissue during thoracoabdominal aortic repair include preoperative recognition of the extent of repair required. In our practice, as a rule-of-thumb, we apply a "20-mm rule" to estimate the aortic length required to both crossclamp and perform an anastomosis. Ideally, at least $20 \mathrm{~mm}$ of disease-free normal caliber aorta is measured on the preoperative computed tomography scan and can offer important clues as to the extent of repair required. In the case of Tully and colleagues, the measurement was $20 \mathrm{~mm}$ distal to the origin of the left subclavian artery. With Marfan syndrome, it is important to balance the risks of the extent of aortic repair against the risk of leaving native aorta behind. In a series of more than 120 patients with Marfan syndrome undergoing open thoracoabdominal aortic repair, $43 \%$ required clamping proximal to the left subclavian artery. ${ }^{1}$ Alternatively, in a patient with Marfan syndrome, moderate aortic insufficiency, and proximal aortic dimensions that were not reported, a 2-staged approach is used. This begins with a procedure to comprehensively address the aortic valve, root, and arch with a valve-sparing root replacement and total arch repair with a frozen elephant trunk. This, in turn, is followed by an open thoracoabdominal aortic repair at a later date that would have facilitated the author's initial intent to avoid clamping the arch. ${ }^{4,5}$

Discussion of informative cases such as this can be enhanced by using the recently updated Society for Vascular Surgery/Society of Thoracic Surgeons classification of aortic dissections. This approach provides a systematic method to clearly convey the location of the entry ear plus the proximal and distal extent of dissection by zone. ${ }^{6}$ The case of Tully and colleagues demonstrates the potential high complexity of aortic surgery, and this author believes that we have reached a stage at which thoracoabdominal aortic repairs should be done in high-volume centers. ${ }^{7,8}$ Similar to the heart team approach for heart failure and aortic stenosis, an aortic center team approach, including high-quality imaging and image analysis, is key to achieving the best results for patients with complex aortic diseases. ${ }^{9}$

\section{References}

1. Coselli JS, Green SY, Price MD, Hash JA, Ouyang Y, Volguina IV, et al. Results of open surgical repair in patients with Marfan syndrome and distal aortic dissection. Ann Thorac Surg. 2016;101:2193-201.

2. Tully L, Lopez- Marco A, Corredor C, Oo A. Mind the gap: transesophageal echocardiography aids detection of pseudo-coarctation during thoracoabdominal surgery. J Thorac Cardiovasc Surg Tech. 2021;6:106-9.

3. Gay WA Jr, Young WG Jr. Pseudocoarctation of the aorta. A reappraisal. J Thorac Cardiovasc Surg. 1969;58:739-45.

4. Coselli JS, LeMaire SA, Köksoy C. Thoracic aortic anastomosis. Op Tech Thorac Cardiovasc Surg. 2000;5:259-76.

5. Roselli EE, Bakaeen FG, Johnston DR, Soltesz EG, Tong MZ. Role of the frozen elephant trunk procedure for chronic aortic dissection. Eur J Cardiothorac Surg. 2017;51(suppl 1):i35-9.

6. Lombardi JV, Hughes GC, Appoo JJ, Bavaria JE, Beck AW, Cambria RP, et al. Society for Vascular Surgery (SVS) and Society of Thoracic Surgeons (STS) reporting standards for type B aortic dissections. Ann Thorac Surg. 2020;109:959-81.

7. Moulakakis KG, Karaolanis G, Antonopoulos CN, Kakisis J, Klonaris C Preventza O, et al. Open repair of thoracoabdominal aortic aneurysms in experienced centers. J Vasc Surg. 2018;68:634-45.e12.

8. Cowan JA Jr, Dimick JB, Henke PK, Huber TS, Stanley JC, Upchurch GR Jr. Surgical treatment of intact thoracoabdominal aortic aneurysms in the United States: hospital and surgeon volume-related outcomes. J Vasc Surg. 2003;37:1169-74.

9. Andersen ND, Benrashid E, Ross AK, Pickett LC, Smith PK, Daneshmand MA et al. The utility of the aortic dissection team: outcomes and insights after a decade of experience. Ann Cardiothorac Surg. 2016;5:194-201. 